\title{
Breast cancer and environmental factors
}

\author{
J Vicente Paulo ${ }^{1 *}$, Lélita Santos ${ }^{2}$, Graça Fernandes ${ }^{3}$ \\ From 16th International Charles Heidelberger Symposium on Cancer Research \\ Coimbra, Portugal. 26-28 September 2010
}

Breast cancer incidence is higher in urban areas and industrialized countries, rather than in less developed ones [1]. The etiology is probably multifactorial and lifestyle and environmental factors account for $73 \%$ of cases [2]. The present study analyzes the eventual relationship between environmental pollutants exposure and population density and the risk of developing breast cancer. It concerns 544 cytological exams during 2008 in our Hospital sorted by age, geographic area, anatomic location, and the cytological results. The environmental pollutants emission reported in 2007 (by the Portuguese Environment Agency) in the Central Region of Portugal was adjusted to the population density of each municipality and statistically analyzed. The prevalence of breast cancer in the municipalities with lower population density and lower allocation of pollutants is $24.3 \%$ vs $13.8 \%$ in areas of higher population density. Three clusters of incidence of breast cancer were identified, one at the coast (Aveiro-Leiria) and two central areas, on the north and centre of Coimbra. The prevalence of breast cancer depends on the level of emission of atmospheric pollutants. We conclude for the influence of environmental risk factors in breast cancer incidence, despite the wideness of the results, which implies that further and more consistent studies have to be done.

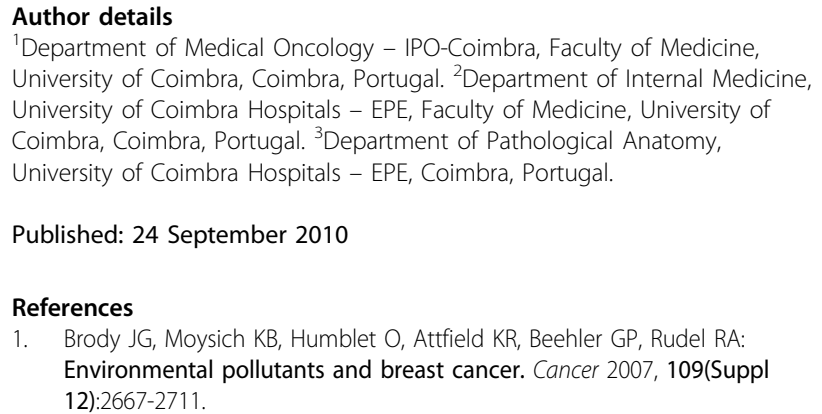

Published: 24 September 2010

\section{References}

1. Brody JG, Moysich KB, Humblet O, Attfield KR, Beehler GP, Rudel RA: Environmental pollutants and breast cancer. Cancer 2007, 109(Suppl 12):2667-2711

\footnotetext{
* Correspondence: judypaulo@gmail.com

'Department of Medical Oncology - IPO-Coimbra, Faculty of Medicine, University of Coimbra, Coimbra, Portugal

Full list of author information is available at the end of the article
}

2. Lichtenstein P, Holm NV, Verkasalo PK, Iliadou A, Kaprio J, Koskenvuo M, Pukkala E, Skytthe A, Hemminki K: Environmental and heritable factors in the causation of cancer - analyses of cohorts of twins from Sweden, Denmark and Finland. N Engl J Med 2000, 343:78-85.

doi:10.1002/cncr.22655

Cite this article as: Paulo et al:: Breast cancer and environmental factors. BMC Proceedings 2010 4(Suppl 2):P7.
Submit your next manuscript to BioMed Central and take full advantage of:

- Convenient online submission

- Thorough peer review

- No space constraints or color figure charges

- Immediate publication on acceptance

- Inclusion in PubMed, CAS, Scopus and Google Scholar

- Research which is freely available for redistribution

Submit your manuscript at www.biomedcentral.com/submit
C Biomed Central 